\title{
1: 150143403-150146572
}

National Cancer Institute

\section{Source}

National Cancer Institute. 1:150143403-150146572. NCI Thesaurus. Code C44963.

Physical location of S100A9_Gene 